\title{
Size-related Change in the Visual Resolution of Sunfish (Lepomis spp.)
}

\author{
William E. Walton \\ Department of Zoology and the College of Life Sciences, University of Maryland, College Park, MD 20742, USA \\ Stephen S. Easter, Jr., and Celeste Malinoski \\ Department of Biology, University of Michigan, Ann Arbor, MI 48109, USA \\ and Nelson G. Hairston, Jr. \\ Section of Ecology and Systematics, Cornell University, Ithaca, NY 14853, USA
}

\begin{abstract}
Walton, W.E., S.S. Easter, Jr., C. Malinoski, and N.G. Hairston, Jr. 1994. Size-related change in the visual resolution of sunfish (Lepomis spp.). Can. J. Fish. Aquat. Sci. 51: 2017-2026.

Visual resolution of juvenile sunfish (Lepomis spp.) (8-33 mm standard length (SL)), although extremely poor in comparison with the larger individuals (38-160 $\mathrm{mm} \mathrm{SL}$ ) used in previous studies, improves rapidly as they grow. Histologically and behaviorally determined (mean reaction angle) visual angles of fish between 10 and $33 \mathrm{~mm}$ SL decrease by approximately 50 and 100 minutes of arc, respectively, and decline nonlinearly with increasing fish size. Behaviorally determined visual resolution of juvenile sunfish based on maximum location distance (MLD) is equivalent to that calculated from intercone spacing. The mean reaction angle used in previous studies may have underestimated behavioral visual resolution of larger ( $>38 \mathrm{~mm} \mathrm{SL}$ ) sunfish by approximately $30 \%$. Visual volume and search volume increase by nearly three orders of magnitude in sunfish between 8 and $50 \mathrm{~mm} \mathrm{SL}$. After sunfish exceed $50 \mathrm{~mm}$ SL (when they can safely return to the pelagic zone), visual resolution increases comparatively slowly as body size increases. Our results suggest that the size-related change in behavioral visual resolution in sunfish is influenced by other factors in addition to the growth-related changes in the resolving power of the retina.
\end{abstract}

La résolution visuelle chez de jeunes crapets (Lepomis spp.) (de 8 à $33 \mathrm{~mm}$ de longueur standard (LS), bien qu'extrêmement faible, comparativement aux individus plus grands (38 à $160 \mathrm{~mm}$ de LS) utilisés dans les études précédentes, augmente rapidement à mesure qu'ils grandissent. Les angles visuels (angles de réaction moyens) déterminés par voie histologique et comportementale chez des poissons de 10 et $33 \mathrm{~mm}$ diminuent respectivement d'environ 50 et 100 minutes d'arc et baissent de façon non linéaire avec la taille des poissons. La résolution visuelle de jeunes crapets déterminée par voie comportementale et fondée sur la distance maximale de localisation (MLD) est équivalente à celle calculée à partir de l'espacement interconique. L'angle moyen de réaction utilisé dans les mesures précédentes de résolution visuelle comportementale de crapets plus grands (>38 mm de LS) a peut-être été sous-estimé de $30 \%$. Le volume visuel et le volume de recherche sont devenus 1000 fois plus élevés chez des crapets de $8 \mathrm{et} 50 \mathrm{~mm}$ de LS. Une fois que les crapets ont dépassé $50 \mathrm{~mm}$ de LS (ils peuvent alors retourner sans danger dans la zone pélagique), la résolution visuelle augmente, mais plus lentement que la taille corporelle. Nos résultats laissent supposer que la variation de résolution visuelle comportementale chez le crapet est fonction d'autres facteurs, en plus de ceux liés à la variation du pouvoir de résolution de la rétine, associée à la croissance.

Received April 7, 1993

Accepted April 8, 1994

Reçu le 7 avril 1993

(J11880)

Accepté le 8 avril 1994

S ize-related changes in visual resolution (Hairston et al. 1982; Breck and Gitter 1983; Li et al. 1985) and search behavior (Brown 1985; Browman and O'Brien 1992a; Wanzenböck 1992) of fish have important implications for measuring prey selectivity, interpreting predator behavior, and testing foraging models. Understanding how ontogenetic changes in visual resolution affect the visual volume, and ultimately prey encounter rate, is relevant to models of feeding ecology and habitat switching (Werner and Hall 1974, 1988; O'Brien et al. 1976, 1989, 1990; Mittelbach 1981, 1984, 1986; Hairston et al. 1982; Breck and Gitter 1983; Werner et al. 1983; Li et al. 1985; Wetterer and Bishop 1985; Walton et al. 1992). Bluegill (Lepomis macrochirus) exhibit ontogenetic niche shifts that are the result of balancing predation risk and foraging returns (Mittelbach 1981,

1984, 1986; Werner and Hall 1988). O'Brien et al. (1989) suggested that the saltatory search behavior observed in bluegill (Janssen 1982; Ehlinger and Wilson 1988) and several other species of planktivorous fish (O'Brien and Evans 1991) is an adaptation to the conflicting demands of predator vigilance and foraging. The geometry of the space scanned for prey by saltatory searching fish is species specific and varies with environmental conditions, prey type, and predator age (O'Brien et al. 1989; Browman et al. 1990; Browman and O'Brien 1992a).

As planktivorous fish grow, so do their abilities to see and to distinguish among prey that differ in size and form. Because visual resolution is directly related to fish size (Baerends et al. 1960; Blaxter and Jones 1967; Blaxter and Staines 1970; Johns and Easter 1977; Rahmann et al. 1979; 
Hairston et al. 1982; Neave 1984; Blaxter 1986; Browman and O'Brien 1992a, 1992b), larger fish search larger visual volumes than do smaller conspecifics (Breck and Gitter 1983; Wanzenböck and Schiemer 1989). In addition to conferring a larger visual volume, the enhanced visual capabilities of large fish are thought to permit a more accurate assessment of prey size, and therefore, of potential energy content and handling time of prey (Li et al. 1985). The ability of large bluegill to maximize foraging returns is important because growth rates are often food limited (Osenberg et al. 1988). The prey detection ability and the visual system of large L. macrochirus (37-165 mm standard length (SL)) have been studied using both behavioral measurements, such as reaction distance (Werner and Hall 1974; Vinyard and O'Brien 1976; Luecke and O'Brien 1981; Hairston et al. 1982; Breck and Gitter 1983; Li et al. 1985) and heart-rate conditioning (Hawryshyn et al. 1988), and anatomical measurements, such as retinoscopical (Sivak 1973) or histological examination of the eye (Hairston et al. 1982; Williamson and Keast 1988). Otten (1981) argued that electrophysiological and ethological studies are needed to evaluate the estimates of visual resolution, and to test the theoretical predictions, derived from studies of the retina.

Even though the retina of a teleost fish grows throughout much of the animal's life (Müller 1952; Johns and Easter 1977; Easter 1992), the change in retinal structure and components of the eye can be dramatic in juvenile fish (Blaxter 1975; Fernald 1988; Sivak 1990). The retina is thought to be a limiting factor in the resolving power of the photopic system during most of a fish's lifetime (Otten 1981; Meer and Anker 1984). However, the highly correlated, size-related changes in behavioral and anatomical visual resolution (e.g., the visual angle subtended by the prey at detection and the minimum separable angle calculated from the distance between photoreceptors in the retina, respectively) observed in relatively large individuals (Hairston et al. 1982; Li et al. 1985) do not necessarily occur in juvenile fish. For example, Neave (1984) found that anatomical and behavioral visual resolution improved at very different rates during development in both larval plaice (Pleuronectes platessa) and turbot (Scophthalmus maximus). The relationship between retinal growth and the visual capabilities of fry and fingerling sunfish has not been studied.

In this paper, we examine the visual resolution of youngof-the-year sunfish (Lepomis spp.) (8-33 mm SL) and compare behavioral and histological measures of visual resolution for these fish. We associate the size-related changes in visual resolution to the life history of bluegill in northtemperate lakes. We also examine growth-related changes in lens size and the distance between cone receptors in the retina for 10 - to $120-\mathrm{mm}$ SL bluegill. We combine our data for young-of-the-year sunfish with those from previous studies of larger bluegill (Hairston et al. 1982; Breck and Gitter 1983; Li et al. 1985) to examine size-related changes in visual resolution, visual field volume, and search volume across a wide range or fish sizes $(8-165 \mathrm{~mm} \mathrm{SL})$.

\section{Materials and Methods}

\section{Study Organisms}

Juvenile sunfish were collected from Dryden Lake, Tompkins County, New York, U.S.A., and maintained in 20-L buckets on a daily ration of mixed zooplankton. Because it is not possible to distinguish morphologically between the fingerlings of closely related Lepomis species, electrophoretic analyses utilizing diagnostic loci (Dawley 1987) were used to determine the species composition of the juvenile fish after they were used in feeding trials. The majority $(80 \%)$ of the fish were bluegill and the remainder were pumpkinseed (Lepomis gibbosus). Small bluegill (20-55 mm SL) and pumpkinseed (20-40 mm SL) are ecologically analogous: their diets and habitat utilization are similar (Mittelbach 1984, 1986; Werner and Hall 1988), and the growth rates for young-of-the-year of both species exhibit similar responses to environmental factors (Osenberg et al. 1988). We did not observe two distinct groupings in any of the measurements described below, and therefore assume that the visual capabilities of small bluegill and pumpkinseed do not differ significantly.

\section{Behaviorial Measurements}

Reaction distances were measured for 36 fish that were distributed among seven size classes $(8,10,14,19,27,30$, and $33 \mathrm{~mm}$ SL). Because individual fish became skittish and did not readily feed, groups of three similarly sized sunfish were used in the predation experiments. Experiments were run in an aquarium $(78 \mathrm{~cm}$ long $\times 57 \mathrm{~cm}$ wide $\times 25 \mathrm{~cm}$ high) constructed of opaque white plastic and with a grid of $1-\mathrm{cm}$ squares marked off on the bottom. In order to keep the fish and prey within the field of view of the video camera, the fish were retained within a clear plexiglass bottomless enclosure $(40.5 \mathrm{~cm}$ long $\times 57 \mathrm{~cm}$ wide $\times 16 \mathrm{~cm}$ high) positioned in the center of the aquarium. Water depth was either $2 \mathrm{~cm}$ (for fish $8-19 \mathrm{~mm} \mathrm{SL}$ ) or $4 \mathrm{~cm}$ (for fish 27-33 mm SL). Light was provided by two $40-\mathrm{W}$ coolwhite fluorescent lamps giving ambient light levels at the water surface of $4-4.5 \mu \mathrm{Ein} \cdot \mathrm{s}^{-1} \cdot \mathrm{m}^{-2}$.

Daphnia pulex were sieved and then sorted by eye and measured (mean length (excluding tail spine) $\pm \mathrm{SD}: 2.0 \pm 0.1$ or $2.4 \pm 0.2 \mathrm{~mm}$ for the small and large bluegill, respectively). They were introduced individually into the aquarium by a pipet. Each prey was placed at the end of the enclosure opposite that occupied by the fish and was initially outside the visual field of the fish. Sham introductions were made throughout the experiments by pipetting water without prey. Sham introductions never evoked a response by the fish.

A video camera was positioned $260 \mathrm{~cm}$ above the water surface to record the positions of the fish's head and the prey. Reaction distance, $d$, was defined as the distance between the fish and the prey at the time the fish oriented toward the prey and initiated pursuit (Vinyard and $O^{\prime} B$ Brien 1976). Errors in the measured reaction distance due to parallax were less than 3\% (Hairston et al. 1982; Walton et al. 1992). Visual angle $(\alpha)$ was calculated as

(1) $\alpha=2 \cdot \arctan \left(h \cdot(2 d)^{-1}\right)$

where $h$ is the mean diameter of the prey (Hairston et al. 1982; $\mathrm{Li}$ et al. 1985) and $d$ is the mean reaction distance. The mean diameter of the prey is approximately $64 \%$ of body length, excluding the tail spine.

In order to compare our data for small sunfish with those for larger conspecifics, we duplicated the behavioral methods of Hairston et al. (1982) and Li et al. (1985). Recent studies suggest, however, that the maximum observed pursuit distance (MxPD: Browman et al. 1990) or the maximum location 
distance (MLD: O'Brien et al. 1990; O'Brien and Evans 1991) is preferable to using the mean reaction distance to calculate behavioral visual resolution for fish utilizing a saltatory search strategy. The MLD is the outer boundary of the distribution of pursuit length (i.e., reaction distance) within which $90 \%$ of the pursuits fall (O'Brien and Evans 1991). We also calculated the visual angle of the MLD and the MxPD for each size category.

\section{Histological Measurements}

Retinal anatomy was examined using light microscopy following the methods of Hairston et al. (1982). Retinae from 11 fish (10-18 mm SL) were fixed in Bouin's solution, dehydrated in ethanol, and embedded in paraffin. Sections (10 $\mu \mathrm{m}$ thick) were mounted and stained with hematoxylin and eosin. The minor diameters of the cone ellipsoids in a radial section through the center of the eye were measured at 10 randomly selected sites under a $100 \times$ oil immersion lens. The number of cones per square millimetre of retinal surface (retinal planimetric density) was corrected for histological artifacts. The Abercrombie correction (Abercrombie 1946; Konigsmark 1970) was used to obtain the number of ellipsoid centers per $10-\mu \mathrm{m}$-thick sample and results were corrected for 30\% linear shrinkage (Johns and Easter 1977; Hairston et al. 1982). The average distance between cones was calculated as the reciprocal of the square root of the retinal planimetric density (Easter et al. 1977; Fisher and Easter 1979). Visual angles were calculated from histological data following the methods of Easter et al. (1977).

We confirmed that the size of the retinal field in the very small sunfish is equivalent to that in the larger sunfish used by Hairston et al. (1982) by examining the angular subtense of the retina with respect to the center of the lens in six small sunfish (10-18 mm SL). The eyes were not excised from the head. Following decapitation, the head of each fish was sectioned parallel to the line connecting the center of the lens and retina with a cryostat microtome. Photographs were taken as the center of the eye was approached. The size and position of the lens relative to the retina were determined from photographic negatives in which the lens and the globe were largest following the methods of Easter et al. (1977).

In order to compare histological and behavioral measures of visual resolution, we assumed that the Helmholtz criterion (Helmholtz 1924) described the relationship between retinal structure and visual resolution, and therefore, the intercone spacing derived from retinal anatomy was multiplied by 2 (Tamura and Wisby 1963; Breck and Gitter 1983; Li et al. 1985). The intercone spacing per degree of visual angle was doubled by $\mathrm{Li}$ et al. (1985) in their study of larger $L$. macrochirus. By also doing so, we can combine our data for juvenile sunfish with data from $\mathrm{Li}$ et al. (1985) and compare visual resolution across a large size range of sunfish $(8-165 \mathrm{~mm} \mathrm{SL})$. The entire range of fish was examined quantitatively by transforming fish size to the inverse of standard length and fitting visual angle to this variable using least squares linear regression. For the behavioral data, the mean visual angle for fish of a particular size from $\mathrm{Li}$ et al. (1985) and this study was used in the regression.

\section{Visual Field and Search Volume}

The visual field volume of each sunfish size class was calculated by assuming a spherical visual field with a radius equal to the class-specific MLD multiplied by 0.69 . The
TABLE 1. Reaction distances (SD in parentheses) and maximum location distances for seven size classes of sunfish.

\begin{tabular}{cccc}
\hline $\begin{array}{c}\text { Size } \\
(\mathrm{mm} \mathrm{SL})\end{array}$ & $N$ & $\begin{array}{c}\text { Mean reaction } \\
\text { distance }(\mathrm{cm})\end{array}$ & $\begin{array}{c}\text { Maximum location } \\
\text { distance }(\mathrm{cm})\end{array}$ \\
\hline 8 & 28 & $3.2(0.8)$ & 4.2 \\
10 & 18 & $4.0(1.4)$ & 5.7 \\
14 & 22 & $5.7(1.7)$ & 7.2 \\
19 & 41 & $7.4(2.8)$ & 9.2 \\
27 & 79 & $19.0(6.1)$ & 27.7 \\
30 & 39 & $19.7(6.8)$ & 30.1 \\
33 & 38 & $25.1(5.7)$ & 31.2 \\
\hline
\end{tabular}

MLD was corrected because the visual field of sunfish is not perfectly spherical (Luecke and O'Brien 1981). The volume of a three-dimensional reconstruction for the $5 \%$ prey location contours illustrated in Luecke and O'Brien (1981) was determined by summation of the average areas for adjacent horizontal slices of the visual field. The areas of horizontal cross sections were determined at $2-\mathrm{cm}$ intervals by digitizing (digitizing pad: Summagraphics, model MM1201, Fairfield, CT 06430, USA; software: 3DED, Laboratory for High Voltage Electron Microscopy, University of Colorado, Boulder, CO 80309, USA). The maximum distance from the fish's eye to the 5\% prey location contour in the horizontal plane surrounding the fish is assumed to be equivalent to the MLD. The correction factor is the ratio $r_{s} / M L D$ where $r_{s}$ is the radius of a sphere with a volume equal to that of the $5 \%$ prey location field. We assumed that the correction factor is independent of fish size. The MLD was not available for the largest fish reported in Li et al. (1985). Because the corrected MLD was found to be nearly equivalent to the mean reaction distance, the latter measure was used as the radius of the visual field volume for sunfish $>60 \mathrm{~mm}$ SL.

The search volume is a pie-shaped wedge of the visual field that is located rostral to the fish's head and within which approximately $90 \%$ of the attacks on prey occur (O'Brien et al. 1989). The search volume of each bluegill size class was estimated as

\section{(2) $\mathrm{SV}=\mathrm{MLD}^{2} \cdot \mathrm{LH} \cdot \mathrm{TH}$}

where SV is the search volume, $\mathrm{LH}$ is the location height, and $\mathrm{TH}$ is equal to one half of the location angle and is measured in radians (O'Brien et al. 1989). The location height is equal to one half of the MLD of the white crappie (Pomoxis annularis: O'Brien et al. 1989). We assumed that this relationship holds for the bluegill. The mean location angle for bluegill $<35 \mathrm{~mm}$ SL was estimated from behavioral observations to be $82^{\circ}$. The location angle of large bluegill is $75^{\circ}$ (O'Brien and Evans 1991) and we used this value for sunfish $>35 \mathrm{~mm}$ SL.

\section{Results}

\section{Behavioral Measurements: Reaction Distance and MLD}

The mean reaction distance increased directly with fish size (Table 1). The mean reaction distance of 33-mm SL fish was nearly eight times that of the fish in the smallest size category. The maximum location distance also increased approximately eightfold across the range of fish examined (Table 1). Mean reaction distances ranged from 66 to $80 \%$ of the MLD recorded for fish in each size category. 


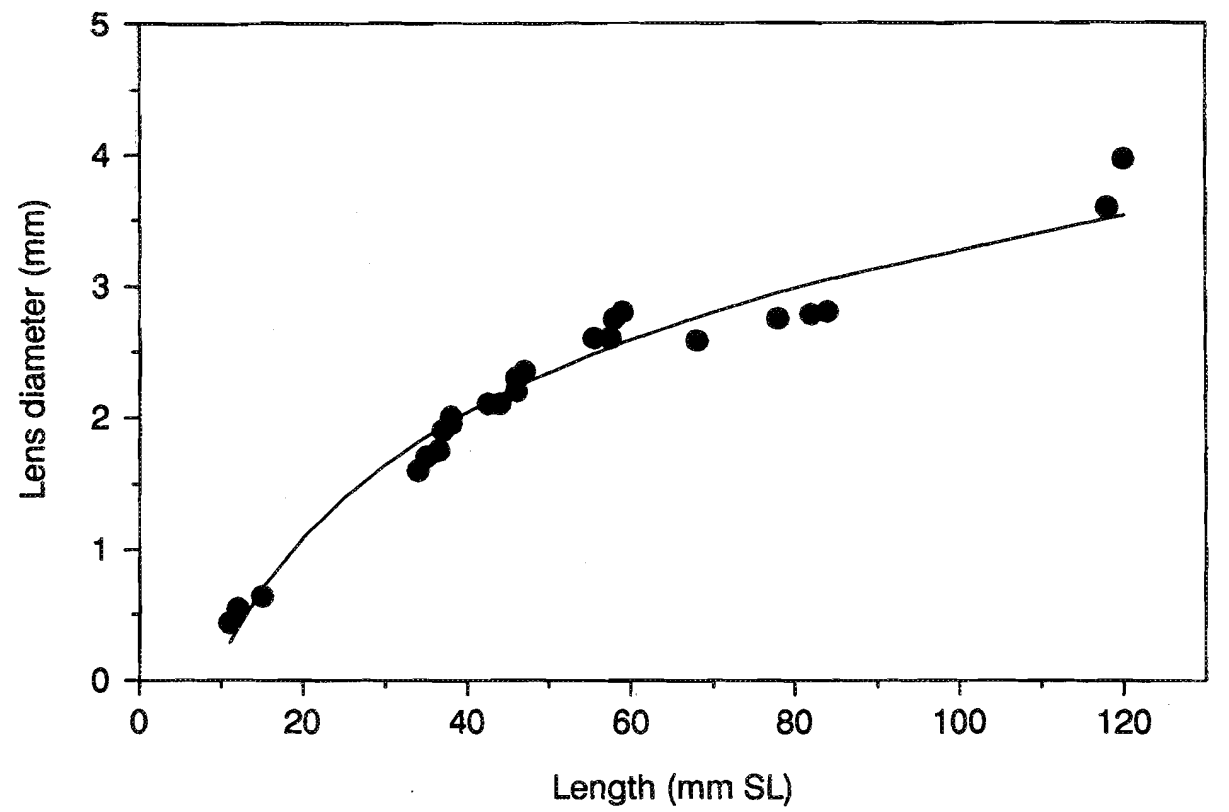

FIG. 1. Lens diameter as a function of sunfish standard length. The line through the data is the best-fitting regression: lens diameter $=1.358(\mathrm{SE}=0.059) \cdot[\ln (\mathrm{SL})]-2.971(\mathrm{SE}=0.228)$, $R^{2}=0.96, \mathrm{RMS}=0.030, N=24$, where $R^{2}$ is the coefficient of determination, RMS is the residual mean square for the regression, $N$ is the sample size, and $\mathrm{SE}$ is the standard error of the regression coefficient.

Histological Measurements

\section{Lens size and position}

Lens diameter increased as a function of body size, but the slope of the relationship declined in large fish (Fig. 1). In 10to 33-mm sunfish, the increase in lens diameter was approximately linear; lens diameter increased from about $0.5 \mathrm{~mm}$ in 10 -mm fish to approximately $1.5 \mathrm{~mm}$ in 33-mm fish (Fig. 1). Thereafter, lens growth slowed as fish length increased.

The position of the lens center relative to the retina indicated that retinal field size was independent of fish size. In 10- to 18-mm sunfish, the lens center was situated in the plane of the pupil (or slightly medial) and the relationship of the lens center to the plane of the pupil and the lens center to the retina suggested that the retina subtended $\geq 180^{\circ}$ of visual angle. Similar relationships were observed in the sunfish used by N.G. Hairston et al. (unpublished data). Therefore, the retinal angle and retinal magnification calculations used previously for larger sunfish were appropriate for sunfish $\leq 33 \mathrm{~mm}$ SL.

\section{Intercone distance and cone diameter}

The average distance between cone receptors in the retina increased linearly with increasing fish size (Fig. 2). The linear distance between the cones in 120 -mm fish was 2.2 times that in $10-\mathrm{mm}$ sunfish. Even though the distance between cone receptors increases directly with fish size, the intercone angles decrease with increasing fish size as the retina enlarges and recedes from the lens center during growth (Fig. 3).

The average cone diameter also increased linearly as a function of fish standard length (Fig. 2). The minor diameter of cone ellipsoids increased from about 2.4 to $3.3 \mu \mathrm{m}$ as sunfish grew from 10 to $60 \mathrm{~mm} \mathrm{SL}$.

Comparison of Visual Resolution Determined by Behavioral and Histological Methods

The general shape of the function, visual angle versus fish standard length, was similar for both measures of visual resolution. The visual angle subtended by the prey, at detection, was inversely related to fish size. In both anatomical and behavioral studies, visual angles decreased markedly with increasing fish size for sunfish $<20 \mathrm{~mm} \mathrm{SL}$ (Fig. 3); our anatomically based visual angles were about $50-60 \%$ of those calculated using the mean reaction distance from the behavioral studies.

Nearly all of the prey detections by sunfish $<20 \mathrm{~mm} \mathrm{SL}$ required an image size that was greater than twice the intercone interval. The proportion of prey detections with an image size greater than twice the intercone interval declined from $>97 \%$ in sunfish $<20 \mathrm{~mm}$ SL to 92 and $66 \%$ in 20- and 33-mm SL sunfish, respectively.

The best fits of body size versus anatomical and behavioral measures (based on the mean reaction angle) of visual resolution were quite different (Fig. 4). The regression lines for both measures of visual resolution diverged noticeably for sunfish $<20 \mathrm{~mm} \mathrm{SL}$. Both the slope and intercept estimates for the two regressions differed significantly (slopes: $t_{47}=$ 13.821, $P<0.001$; intercepts: $t_{47}=3.081, P<0.025$ ).

The variation around the mean behavioral visual angle declined as fish size increased (Fig. 3). The variation in visual angles for 8- to 19-mm SL sunfish was approximately three times $( \pm 30-40$ minutes of arc) that observed for $>25-\mathrm{mm}$ SL fish; however, this trend was opposite that observed for the mean reaction distance (Table 1). Even if the variation around the mean reaction distance of each fish size class were equivalent, the variation around the mean visual angle of small fish would have been larger than the variation around the mean visual angle of large fish because the arctangent function approaches the $x$-axis asymptotically.

Whereas the visual angles calculated using the mean reaction distance were approximately two times larger than those determined by doubling the intercone distance, visual angles calculated using the MLD or the MxPD were similar to 


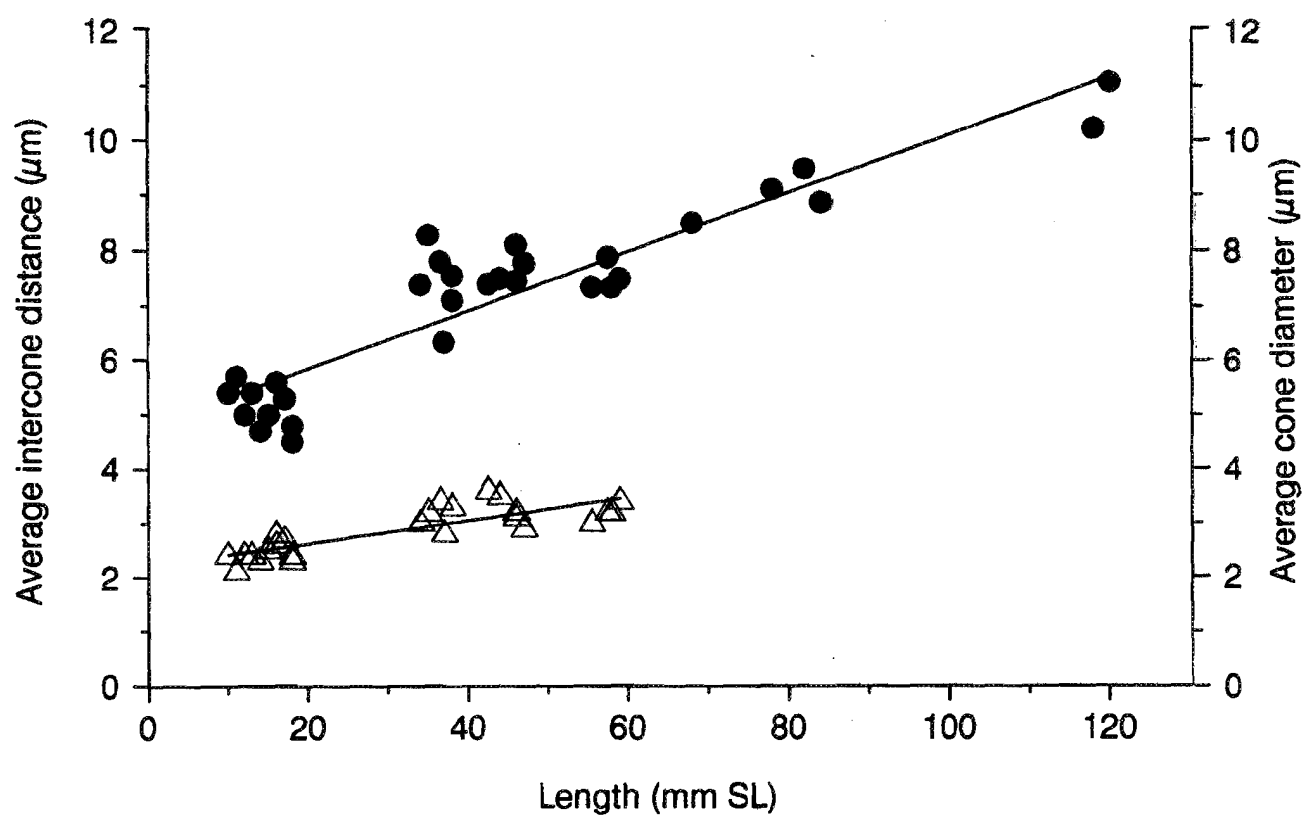

FIG. 2. Average distance between cone receptors (•) and the average diameter of cone receptors $(\Delta)$ in the retinae of sunfish. The best-fitting regressions are shown: average intercone distance $=0.053(\mathrm{SE}=0.004) \cdot \mathrm{SL}+4.793(\mathrm{SE}=0.202), R^{2}=0.86, \mathrm{RMS}=0.405, N=32$; average cone diameter $=2.200(\mathrm{SE}=0.109) \cdot \mathrm{SL}+0.021(\mathrm{SE}=0.003), R^{2}=0.68, \mathrm{RMS}=0.064$, $N=25$. Abbreviations are the same as in Fig. 1 .

those based on twice the intercone distance in the small sunfish (Fig. 3). Behavioral visual resolution based on the MLD or the MxPD also increased nonlinearly with increasing fish size.

\section{Visual Field and Search Volume}

Based on a three-dimensional reconstruction (Fig. 5) using the contours of prey location ability from Luecke and O'Brien (1981), the volume of the visual field was estimated to be one third that of a sphere with a radius equal to the maximum reaction distance in the horizontal plane of the fish. It is assumed that the maximum reaction distance for the 5\% prey detection contour in the horizontal plane of the fish approximates the MLD. This is a reasonable assumption because the ability of sunfish to detect prey changes rapidly with increasing distance from the fish (cf. 95 and 5\% prey detection contours in Fig. 5); the outer boundry within which $90 \%$ of the pursuits fall is likely to be close to the $5 \%$ prey detection contour. An equivalent spherical volume for the visual field bounded by the $5 \%$ prey detection contour has a radius equal to 0.69.MLD. The radius of the visual field approximates the mean reaction distance in the horizontal plane of the fish which, in the small sunfish (Table 1), averaged $74 \%$ of the MLD.

Size-related changes in visual resolution, visual field volume, and search volume were greatest for the small sunfish $(<20 \mathrm{~mm} \mathrm{SL})$. As anatomically based visual angles declined precipitously in small sunfish, visual field volume and search volume increased conversely (Fig. 6). For bluegill viewing a 2-mm Daphnia, the volume of the visual field increased from $0.14 \mathrm{~L}$ for an 8-mm SL sunfish to nearly $217 \mathrm{~L}$ for a $160-\mathrm{mm}$ SL sunfish. The search volume was on average $22 \%$ (range $17-26 \%$ ) of the visual field volume. The search volume of bluegill viewing a 2-mm Daphnia increased from $0.027 \mathrm{~L}$ for an 8-mm SL fish to nearly $37 \mathrm{~L}$ for a $160-\mathrm{mm}$ SL fish.

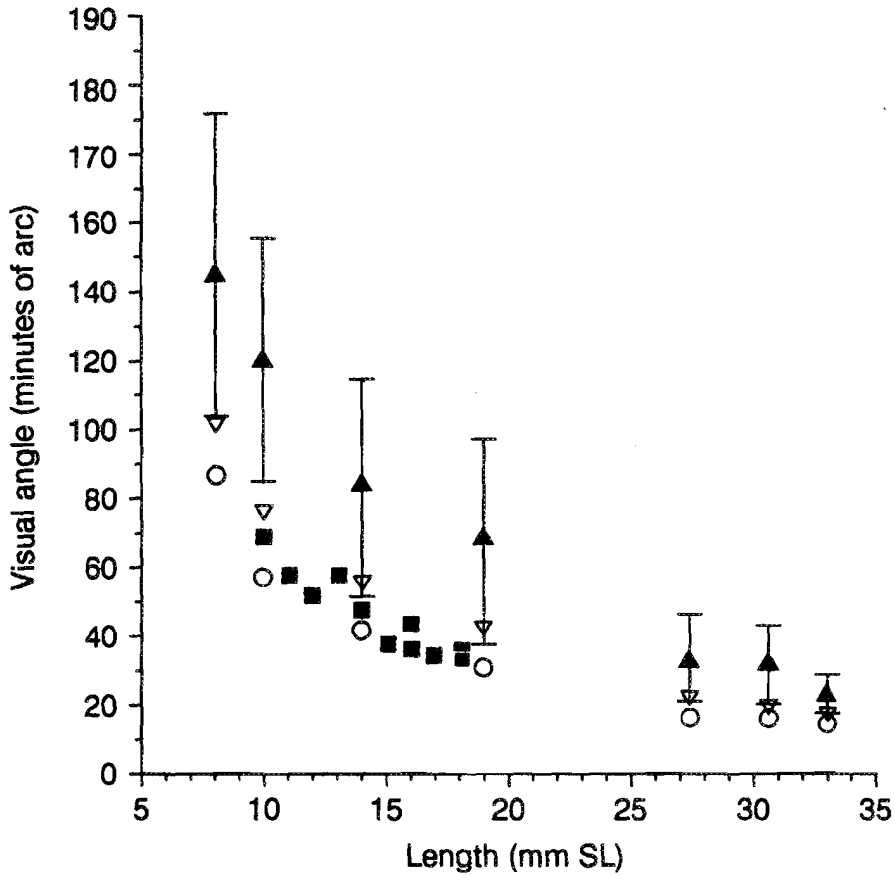

FIG. 3. Visual resolution of juvenile sunfish. A, mean visual angle $( \pm \mathrm{SD})$ calculated from reaction distance; $\mathbf{n}$, visual angle calculated from histological sections (intercone spacing multiplied by 2$) ; \nabla$, visual angle calculated from the maximum location distance; $O$, visual angle calculated from the maximum observed pursuit distance.

\section{Discussion}

\section{Size-related Change of Visual Resolution}

The visual resolution of sunfish improves monotonically with increasing body size and changes rapidly in young-of-the- 


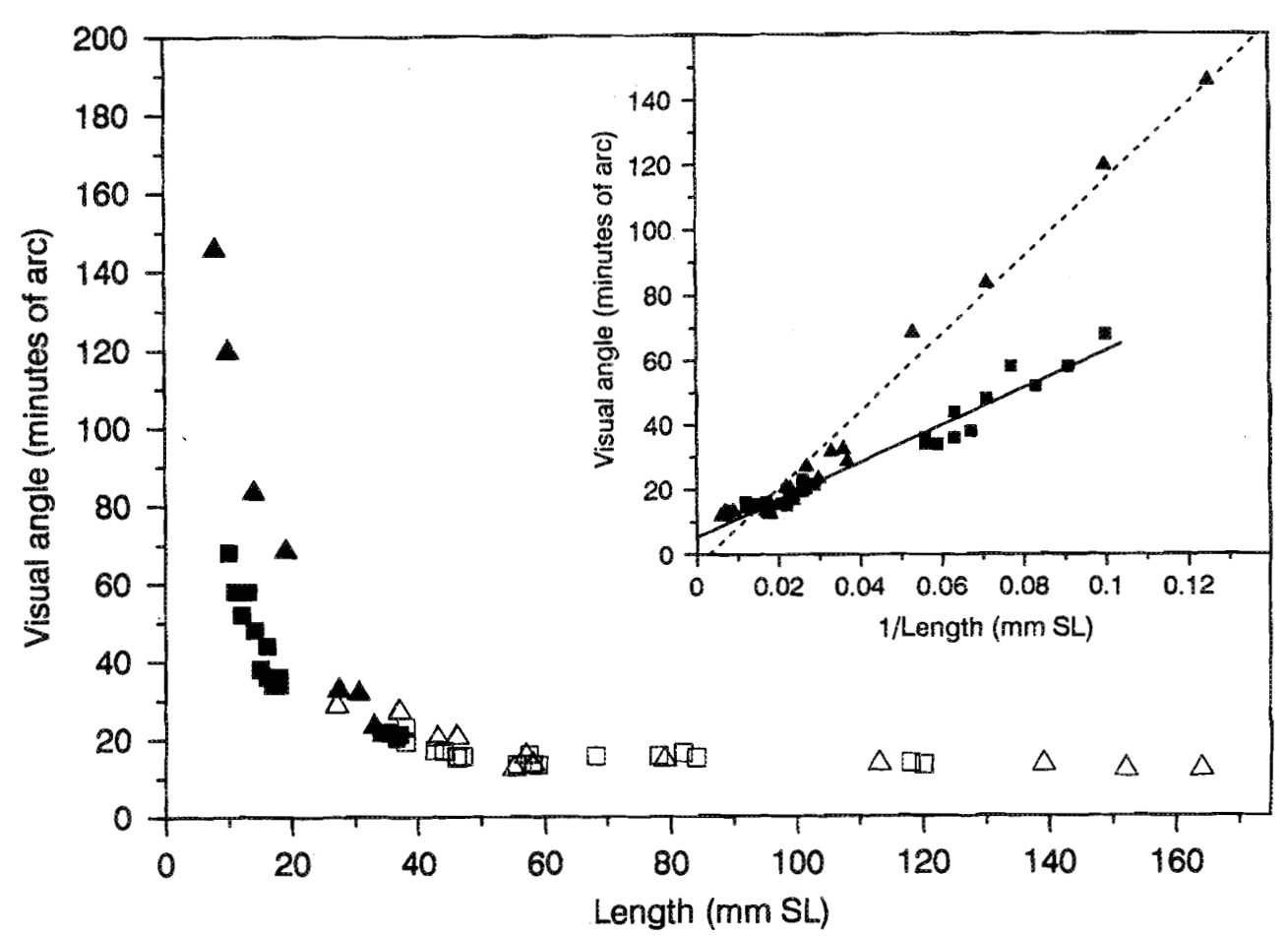

FIG. 4. Change in the visual resolution of sunfish as a function of fish body size. 4 , mean visual angle calculated from reaction distance; $\mathbf{a}$, visual angle calculated from histological sections (intercone spacing multiplied by 2). The data for fish $>35 \mathrm{~mm}$ SL (open symbols) were taken from Hairston et al. (1982) and Li et al. (1985). Inset: linear regressions of visual angle on fish standard length ${ }^{-1}$ for behavioral (..., mean reaction angle) and histological $(-)$ measures. Behavioral visual angle $=1188.70(\mathrm{SE}=45.68) \cdot \mathrm{mm}^{-1}-3.58(\mathrm{SE}=2.13), R^{2}=$ $0.98, \mathrm{RMS}=39.273, N=19$. Histological visual angle $=555.57(\mathrm{SE}=22.06) \cdot \mathrm{mm}^{-1}+7.11(\mathrm{SE}=$ $1.01), R^{2}=0.96, \mathrm{RMS}=10.842, N=32$. Abbreviations are the same as in Fig. 1.

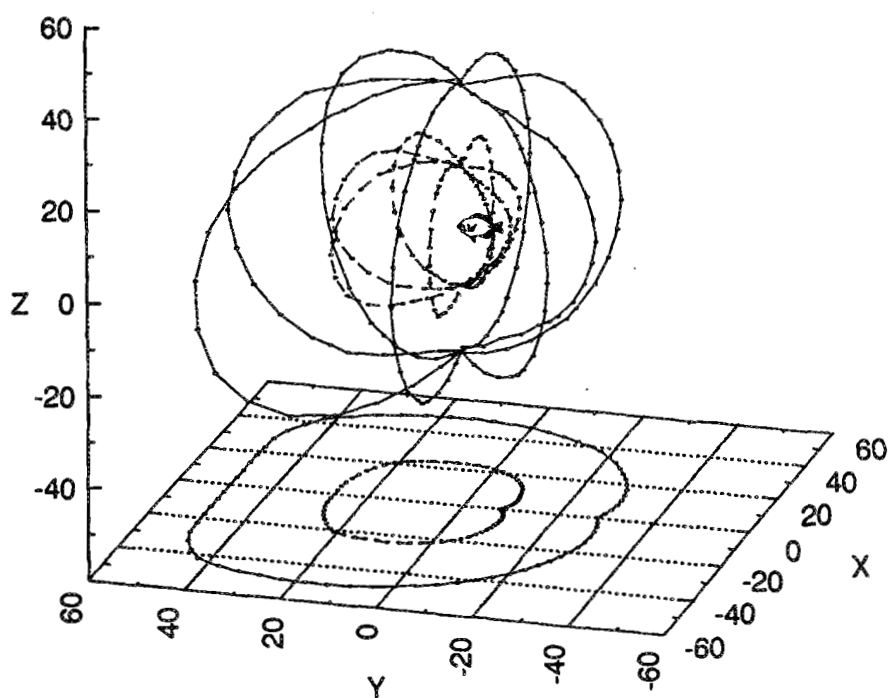

FIG. 5. Visual field of a bluegill $(-56 \mathrm{~mm}$ SL) searching for a 2-mm Daphnia under high light levels $(\sim 59001 \mathrm{x})$. The threedimensional reconstruction is based on data for 5- to 9-cm (total length) bluegill in Luecke and O'Brien (1981). The contours circumscribing the regions where prey are detected in $95 \%$ of the trials (contour closer to the fish) and in $5 \%$ of the trials (contour farther from fish) are illustrated. The projections of both contours onto the $x-y$ plane are illustrated. The fish is positioned at the origin and the scale of the axes is centimetres.

year fish. Visual resolution of the small sunfish (8-33 mm SL) examined both histologically and behaviorally in this study was less acute than that of larger sunfish ( $238 \mathrm{~mm}$ SL: Hairston et al. 1982; Breck and Gitter 1983; Li et al. 1985). As sunfish grew from 10 to $38 \mathrm{~mm}$, histologically and behaviorally determined (mean reaction angle) visual angles decreased by approximately 50 and 100 minutes of arc, respectively. The MLD increased more than fivefold during this interval. Behavioral visual resolution based on the MLD was, however, more similar to histological visual resolution based on twice the intercone interval than was behavioral visual resolution calculated using the mean reaction angle.

The marked improvement in visual resolution observed in juvenile bluegill is also observed in other teleosts. At 2 wk after hatching ( $8 \mathrm{~mm}$ SL), bluegill behavioral visual resolution was estimated from the MLD at $1^{\circ} 43^{\prime}$. At about 3 mo after hatching ( $33 \mathrm{~mm} \mathrm{SL)}$, behavioral visual resolution was estimated to be $18^{\prime}$. Neave (1984) found that the behavioral visual angles of larval plaice $\left(6-7^{\circ}\right)$ and turbot $\left(5-6^{\circ}\right)$ at the age of first feeding exceeded the minimum separable visual angle based on cone cell spacing ( $1^{\circ}$ and $1^{\circ} 20^{\prime}$, respectively). Behaviorally determined visual angles of both species decreased appreciably during larval development and were smaller at metamorphosis (both species: $11^{\prime}$ ) than were histologically based visual angles (plaice: $40^{\prime}$, turbot: $20^{\prime}$ ). In larval Atlantic herring (Clupea harengus), a simple retina is retained for months after hatching, and the visual resolution of $10-\mathrm{mm}$ larvae using the unspecialized retina was estimated from histological preparations to be $200^{\prime}$ (Blaxter and Jones 1967). The minimum separable visual angle declined steeply in herring $<50 \mathrm{~mm}$ and declined more slowly in fish larger than $50 \mathrm{~mm}$ (Blaxter and Jones 1967, Blaxter 1975). At 


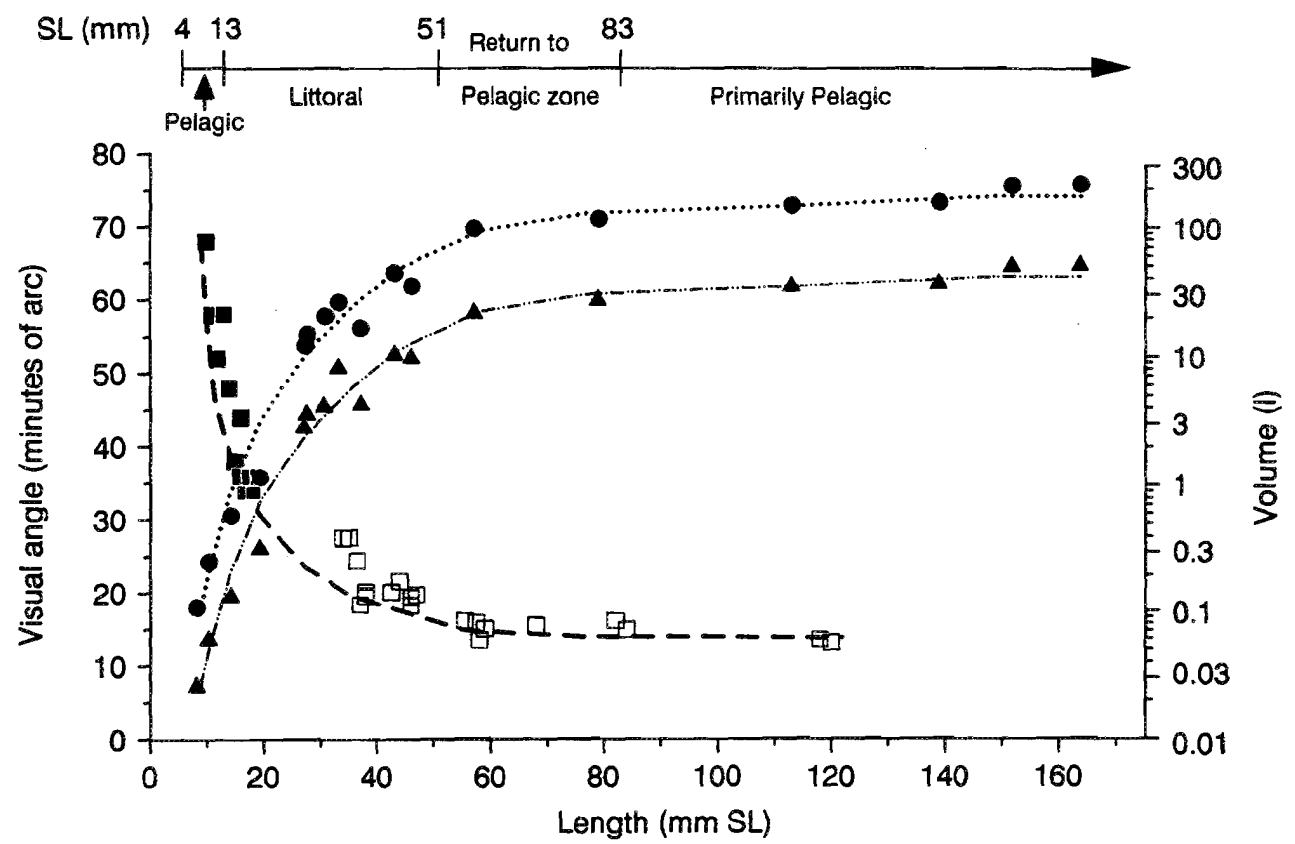

FiG. 6. Comparison of the size-related change of histologically determined visual resolution ( $\mathbf{a}$, this study; $\square$, Hairston et al. 1982; Li et al. 1985) versus visual field volume (e) and search volume (A) of bluegill searching for a $2-\mathrm{mm}$ Daphnia. The visual field volume is assumed to be spherical with a radius equal to the $0.69 \cdot \mathrm{MLD}$ (or the mean reaction distance (see text)). The search volume is a rostral, triangular wedge of the visual field as defined by O'Brien et al. (1989). The size-related change in habitat preference for bluegill populations inhabiting small lakes in southwestern Michigan (Werner and Hall 1988) is shown at the top of the figure. The vertical lines and numbers indicate the standard length at which major changes in habitat preference occur.

$300 \mathrm{~mm}$, the visual resolution improved to $25^{\prime}$ in the unspecialized region of the retina and was estimated to be $7^{\prime}$ in the area temporalis (Blaxter and Jones 1967). Behavioral visual resolution in larval rainbow trout (Oncorhynchus mykiss) improved from $2^{\circ}$ shortly after hatching to $18-28^{\prime}$ at $68 \mathrm{~d}$ after hatching (Rahmann et al. 1979). Histologically determined visual resolution of yellow perch (Perca flavescens) improved from $174^{\prime}$ in newly hatched larvae to 9-12' in the adult (>200 mm SL: Wahl et al. 1993).

The sharp decline in the histological visual angle as fish grew was accompanied by a comparatively abrupt increase in the visual volume. The eyes of the smallest sunfish have poor visual resolution and are capable of searching only small visual volumes ( $<1 \mathrm{~L}$ : Fig. 6). Bluegill fry remain on the nest for 4-10 d after hatching before leaving the nest at about $4 \mathrm{~mm} \mathrm{SL}$ to reside in the pelagic zone for a period of 4-7 wk (Werner 1967; Beard 1982; Werner and Hall 1988). At approximately 12-14 mm SL, bluegill fry return to the littoral zone and reside in and near littoral vegetation for several years (Werner and Hall 1988). During the period when bluegill emigrate from, return to, and then reside in the littoral zone, the eye continues to grow and the minimum separable visual angle calculated from intercone spacing declines markedly from approximately $1^{\circ} 10^{\prime}$ in $10-\mathrm{mm} \mathrm{SL}$ individuals to $17^{\prime}$ of arc in 50-mm SL sunfish (Fig. 6). Visual volume increases nearly three orders of magnitude, from about $0.1 \mathrm{~L}$ at $8 \mathrm{~mm} \mathrm{SL}$ to $90 \mathrm{~L}$ at $50 \mathrm{~mm} \mathrm{SL}$.

Hairston et al. (1982) suggested that a selective advantage provided by continuous retinal growth was the improved prey detection abilities of larger fish: the potential of larger retinae to resolve smaller objects. As visual volume increases, larger sunfish are able to discern smaller prey at greater distances and also see more prey than can small fish in the same environment (Hairston et al. 1982). Enhanced visual capabilities are also thought to permit a more accurate assessment of prey size and, therefore, of the potential energy content and handling time of prey ( $\mathrm{Li}$ et al. 1985). Such improvements in visual resolution are presumably significant for a sunfish to maximize its energetic intake. For example, the inclusion of suboptimal prey in the diet has a smaller total effect on energetic intake as fish size decreases (Mittelbach 1981), suggesting that factors that augment prey selection ability, such as better visual resolution, are particularly important to large sunfish. Further, the growth rates of large bluegill in small Michigan lakes were strongly associated with zooplankton profitabilities and were probably food limited (Osenberg et al. 1988).

Visual resolution changes gradually in large, predominantly planktivorous bluegill ( $>50 \mathrm{~mm}$ SL: Fig. 6); yet small changes in visual resolution result in substantial differences in visual volume as fish grow. After 2-4 $\mathrm{yr}$ in the littoral zone, bluegill between 51 and $100 \mathrm{~mm}$ SL switch seasonally from the littoral vegetation to the open-water habitat (Mittelbach 1981) or reside almost exclusively in the pelagic zone (Werner and Hall 1988). Werner and Hall (1988) found that bluegill returned to the pelagic zone at sizes between 51 and $83 \mathrm{~mm} \mathrm{SL}$, and further that the size at which bluegill returned to the pelagic zone was directly correlated with the abundance of piscivores. Visual resolution changes very little and visual volume increases at a comparatively slow rate after bluegill attain the size $(51 \mathrm{~mm} \mathrm{SL})$ at which they return to the open-water habitat (Fig. 6). The minimum separable 
visual angle calculated from histological preparations decreases from about $17^{\prime}$ in $50-\mathrm{mm}$ SL fish to $13^{\prime}$ in $120-\mathrm{mm}$ $\mathrm{SL}$ fish. Even though visual volume increases slowly in bluegill $>50 \mathrm{~mm} \mathrm{SL}$, the visual volume of a $160-\mathrm{mm}$ SL fish viewing a $2-\mathrm{mm}$ Daphnia is 2.3 times larger than for a $50-\mathrm{mm}$ SL fish.

Because the mean (or median) reaction angle was used to estimate the behavioral visual resolution of the larger sunfish used in previous studies (Hairston et al. 1982; Breck and Gitter 1983; Li et al. 1985), behavioral visual resolution was underestimated. If the reaction angle for the MLD is substituted for the mean reaction angle, then the behavioral visual angles of the sunfish used by Hairston et al. (1982) were overestimated by approximately $30 \%$ (range 14-44\%). Li et al.'s (1985) reanalysis of the data from Hairston et al. (1982) and from several other studies (Werner and Hall 1974; Vinyard and O'Brien 1976; Breck and Gitter 1983) showed that the mean reaction angles from behavioral studies for sunfish between 37 and $120 \mathrm{~mm}$ SL were equivalent to anatomically determined visual angles after the latter were doubled in accordance with the Helmholtz criterion. Reaction angles calculated using the MLD are smaller than the mean reaction angles from a particular sunfish size class. The behavioral visual resolution of an adult bluegill is therefore better than the visual resolution calculated from a composite measure of intercone spacing. The distribution of photoreceptors in the retina of adult bluegill is relatively uniform (Williamson and Keast 1988) as compared with marine teleosts (Easter 1992) and other centrarchids (Williamson and Keast 1988; Browman et al. 1990; Cameron and Easter 1993); however, the reaction angle of a $120-\mathrm{mm}$ SL bluegill (10': mean reaction angle reduced by $30 \%)$ is still larger than the minimum separable angle calculated from cone cell spacing in the region of greatest photoreceptor density $\left(5.4^{\prime}\right.$ : twice the intercone distance in the dorsotemporal region of the retina reported by Williamson and Keast (1988)). Hairston et al. (1982) cautioned against assigning much significance to the differences between histological and behavioral measures of visual resolution because of uncertainties associated with each measure such as absolute prey size, histological artifacts, and slight intraretinal regional differences that might affect prey detection and the average intercone distance. Methodological differences complicate comparisons among studies. For fish that use a saltatory search pattern, the MxPD and MLD are clearly better measures of the absolute visual capabilities (minimum separable visual angle) than is the mean reaction distance (Browman et al. 1990; O'Brien et al. 1990).

Bluegill concentrate their attacks on prey positioned in a comparatively small space in the visual field, and it is therefore unlikely that the mean reaction distance for such attacks should approximate the radius of a spherical equivalent to the visual field volume. We conclude that the equivalence of the mean reaction distance and the radius of the visual field volume is coincidental. Even though the eyes are positioned laterally and bluegill can detect prey that are positioned caudally in the visual field, attacks on prey located in the caudal hemisphere of the visual field are relatively rare (O'Brien and Evans 1991; this study). The detection ability of bluegill is greatest for prey positioned at $45^{\circ}$ rostrally to the longitudinal (rostrocaudal) axis in the horizontal plane of the fish; prey detection ability declines both dorsoventrally and laterally to the fish's head (Luecke and
O'Brien 1981). Bluegill and other planktivorous fish concentrate attacks on prey in the forward-directed hemisphere (Dunbrack and Dill 1984; O'Brien et al. 1989, 1990; O'Brien and Evans 1991): a space that, at the low prey densities used here, is only $17-26 \%$ of the bluegill's visual field volume. For a cruising predator such as juvenile coho salmon (Oncorhynchus kisutch), forward-directed locomotion or the movement of stream water past a stationary fish skews the distribution of encounters to prey located rostrally (Dunbrack and Dill 1984). This encounter bias is less likely to occur for a bluegill that restricts scanning for prey to pauses in locomotion and forages in more quiescent lentic environments. There may be a cost (i.e., energetic or time) to reorientation in a lateral or caudal direction; however, the cost of changing direction or scanning the entire visual field would likely be small relative to the cost of pausing. The cost of braking could be considerable, particularly after fast pursuits (O'Brien et al. 1989). The forward-directed bias of prey attacks may be caused by a forward-directed region of slightly higher visual resolution and a tendency to attack prey that are located within or near a region of binocular vision. Based on the direction of accommodative lens movement, the occurrence of an aphakic space (Sivak 1973), and neurophysiological (Schwassman and Kruger 1965) and behavioral evidence, Wetterer (1989) argued that vision in bluegill is primarily forward directed and, if bluegill require binocular cues to evaluate actual prey size and distance of prey, they would be able to do so only when the prey occurs within the bluegill's binocular field of approximately $40^{\circ}$. The location angles of the small bluegill examined here were, on average, only slightly greater than those of larger conspecifics (O'Brien and Evans 1991); this was unlike the dramatic, size-related change in reaction distance.

\section{Image Size and Quality}

Behavioral observations indicate that prey detection by small bluegill requires a large image and suggest that the image might be blurred. Prey detection by very small sunfish ( $<20 \mathrm{~mm}$ SL) required images that, in most instances, were greater than two times the average intercone spacing. The proportion of prey detections with an image size greater than twice the intercone interval declined with increasing fish size for the sunfish examined here and for the intermediate-sized sunfish used by Hairston et al. $(1982 ;<40 \%$ in 55- to 58-mm SL bluegill: J.K. Wetterer, Museum of Comparative Zoology, Harvard University, Cambridge, MA 02138, USA, personal communication). Both cognitive factors, such as learning (Meyer 1986) and prey recognition (Hughes 1979), and ontogenetic improvements in the visual system affect the size-related changes of behaviorally determined visual resolution.

Evolutionary solutions that improve visual resolution during development may involve different parts of the visual system in different fish species (see Otten 1981; Muntz 1990). In addition to cone cell size and spacing, resolution increases with eye size and depends on aperture size (pupil diameter), neuronal connectivity, and lens quality (Muntz 1974; Baxter 1975; Fernald 1988; Sivak 1990). Aperture size limits the resolving power of only very small eyes (Haplochromis elegans: lens diameter $<0.5 \mathrm{~mm}$; Otten 1981). Browman et al. (1990) suggested that the disparity between measures of anatomical and behavioral visual resolution resulted from overestimates of visual resolution by anatomical 
measures that fail to account for cone cell convergence onto ganglion cells and higher brain centers (but see Sivak 1990). Collin and Pettigrew (1989) found that visual resolution calculated from ganglion cell spacing was highly correlated with, and was of comparable magnitude to, that based on cone cell density from previous studies of marine teleosts. The degree of neural summation in the retina of the adult bluegill is intermediate among fish in general and low among the centrarchids (Williamson and Keast 1988). Wagner (1978) argued that the significance of spatial visual function (i.e., lateral inhibition) in the visual system is the possibility to compensate for the blurred image of an object on the retina caused by stray light or for a blurred stimulus pattern caused by divergent neural impulses. For young fish, the spatial visual function typically lags behind the structural maturation of the cone cells (Powers and Raymond 1990)

The relative importance of size-related differences in lens quality (Sivak and Bobier 1978; Kruezer and Sivak 1984; Fernald and Wright 1985a; Sivak 1990) and accommodative mechanisms that move the lens and focus the image onto the retina (Sivak 1973; Fernald and Wright 1985b) is unknown for small sunfish. Lens diameter increases rapidly in juvenile fishes and the lens grows more slowly in larger individuals (Zaunreiter et al. 1991; Wahl et al. 1993; this study). In adult fish, resolution of the lens is typically much smaller than the minimum separable visual angles calculated using the distance between photoreceptors in the retina (Northmore and Dvorak 1979; Fernald 1988). Lens quality in several fish species improved with increasing fish size (Muntz 1974) and was often optimal in sexually mature individuals of intermediate age (Sivak 1990). Any of the aforementioned factors could cause blurring of the image on the retinae of small sunfish and merit further investigation. The present study shows that the nonlinearities in behavioral visual resolution are closely associated with changes in the resolving power of the retina, but our results suggest that the size-related change of behavioral visual resolution in sunfish is influenced by other factors in addition to the growth-related changes in cone cell spacing and lens focal length.

\section{Acknowledgments}

This study was supported by USDA Hatch Project NY(C)183424 to N.G.H., NIH grant EY-00168 to S.S.E., and an award from the College of Life Sciences at the University of Maryland to W.E.W. We benefitted from discussions with D. Cameron, T. Ehlinger, D. Hambright, R. Payne, J. Presson, J. Sivak, P. Walton, J. Wetterer, and H. Yan. We thank R. Dawley for performing the electrophoretic analyses and H. Howland, W.N. McFarland, and A.N. Popper for lending equipment and their helpful suggestions about aspects of this study.

\section{References}

ABERCROMBIE, M. 1946. Estimation of nuclear population from microtome section. Anat. Rec. 94: 239-247.

Baerends, G.P., B.E. Bennema, AND A.A. Vogelzang. 1960. Über die Änderung der Sehschårfe mit dem Wachstum bei Aequidens portalegrensis (Hensel) (Pisces, Cichlidae). Zool. Jb. Geogr. 88: 67--78.

BEARD, T.D. 1982. Population dynamics of young-of-the-year bluegill. Wis. Dep. Nat. Resour. Tech. Bull. 127: 32 p.

BLAXTER, J.H.S. 1975. The eyes of larval fish, p. 427-443. In M.A. Ali [ed.] Vision in fishes. Plenum Press, New York, N.Y.

BLAXTER, J.H.S. 1986. Development of sense organs and behavior of teleost with special reference to feeding and predator avoidance. Trans. Am. Fish. Soc. 115: $98-114$.
Blaxter, J.H.S., AND M.P. JONES. 1967. The development of the retina and retinomotor responses in the herring. J. Mar. Biol. Assoc. U.K. 47: $677-697$.

BlaXter, J.H.S., AND M. Staines. 1970. Pure-cone retinae and retinomotor responses in larval teleosts. J. Mar. Biol. Assoc. U.K. 50: 162-167.

BRECK, J.E., AND M.J. GiTTER. 1983. Effect of fish size on the reaction distance of bluegill (Lepomis macrochirus) sunfish. Can. J. Fish. Aquat. Sci. 40: 162-167.

BROWN, J.A. 1985. The adaptive significance of behavioural ontogeny in some centrarchid fishes. Environ. Biol. Fishes 13: 25-34.

Browman, H.I., W.C. Gordon, B.I. Evans, and W.J. O'Brien. 1990. Correlation between histological and behavioral measures of visual acuity in a zooplanktivorous fish, the white crappie (Pomoxis annularis). Brain Behav. Evol. 35: 85 -97.

Browman, H.I., AND W.J. O'Brien. 1992a. The ontogeny of search behavior in the white crappie, Pomoxis annularis. Environ. Biol. Fishes 34: $181-195$.

Browman, H.I., AND W.J. O'BRIEN. 1992b. Foraging and prey search behaviour of golden shiner (Notemigonus crysoleucas) larvae. Can. J. Fish. Aquat. Sci. 49: 813-819.

Cameron, D.A., AND S.S. EASTER, JR. 1993. The cone photoreceptor mosaic of the green sunfish, Lepomis cyanellus. Visual Neurosci. 10: $375-384$.

Collin, S.P., AND J.D. PETTIGREw. 1989. Quantitative comparison of the limits on visual spatial resolution set by the ganglion cell layer in twelve species of reef teleosts. Brain Behav. Ecol. 34: 184-192.

DAWLEY, R. 1987. Hybridization and polyploidy in a community of three sunfish species. Copeia 1987: 326-335.

DUNBRACK, R.L., AND L.M. DILL. 1984. Three-dimensional prey reaction field of the juvenile coho salmon (Oncorhynchus kisutch). Can. J. Fish. Aquat. Sci. 41: 1176-1182.

EASTER, S.S. JR. 1992. Retinal growth in foveated teleosts: nasotemporal asymmetry keeps the fovea in temporal retina. J. Neurosci. 12: 2381-2392.

EASTER, S.S. JR., P.R. Johns, AND L.R. BaumanN. 1977. Growth of the adult goldfish eye - I. Optics. Vision Res. 17: 469-477.

EHLINGER, T.J., AND D.S. WILSON. 1988. Complex foraging polymorphism in bluegill sunfish. Proc. Natl. Acad. Sci. USA 85: 1878-1882.

FERNAld, R.D. 1988. Aquatic adaptations in fish eyes, p. 435-466. In J. Atema, R.R. Fay, A.N. Popper and W.N. Tavolga [ed.] Sensory biology of aquatic animals. Springer-Verlag, New York, N.Y.

FERnALD, R.D., AND S. WRIGHT. 1985a. Growth of the visual system of the African cichlid fish, $H$. burtoni: optics. Vision Res. 25: 155-161.

FERNALD, R.D., AND S. WRIGHT. 1985b. Growth of the visual system of the African cichlid fish, $H$. burtoni: accommodation. Vision Res. 25: $163-170$.

FiSHER, L.J., AND S.S. EASTER, JR, 1979. Retinal synaptic arrays: continuing development in the adult goldfish. J. Comp. Neurol. 185: 373-380.

Hairston, N.G. JR., K.T. LI, AND S.S. EAster, JR. 1982. Fish vision and the detection of planktonic prey. Science (Wash., D.C.) 218: 1240-1242.

HaWryshyn, C.W., M.G. ARNOLD, W.N. MCFARLand, and E.R. LoEW. 1988. Aspects of color vision in bluegill sunfish (Lepomis macrochirus): ecological and evolutionary relevance. J. Comp. Physiol. A 164: $107-116$.

Helmholtz, H. voN, 1924. Physiological optics. Vol. 2. (Transl. from German by J.P. Southall [ed.], Optical Society of America. George Banta Publishing, Menasha. Wis.)

HUGHES, R.N. 1979. Optimal diets under the energy maximization premise: the effects of recognition time and learning. Am. Nat. 113: 209-221.

JANSSEN, J. 1982. Comparison of the searching behavior for zooplankton in an obligate planktivore, blueback herring (Alosa aestivalis) and a facultative planktivore, bluegill (Lepomis macrochirus). Can. J. Fish. Aquat. Sci. 39: 1649-1654.

JoHNS, P.R., AND S.S. EASTER, JR. 1977. Growth of the aduit goldfish eye. II. Increase in retinal cell number. J. Comp. Neurol. 176: 331-342.

KONIGSMARK, B.W. 1970. Methods for counting of neurons, p. 315-339. In W.J.H. Nauta and S.O.E. Ebbesson [ed.] Contemporary research methods in neuroanatomy. Springer-Verlag, Berlin.

KRUEZER, R.O., AND J.G. SIVAK. 1984. Spherical aberration of the fish lens: interspecies variation and age. J. Comp. Physiol. A 154: 415-422.

LI, K.T., J.K. WeTterer, AND N.G. HAirston, JR. 1985. Fish size, visual resolution, and prey selectivity. Ecology 66:1729-1735.

LUECKE, C., AND W.J. O'BRIEN. 1981. Prey location volume of a planktivorous fish: a new measure of prey vulnerability. Can. J. Fish. Aquat. Sci. 38: $1264-1270$.

MEER, H.J. VAN DER, AND G.C. ANKER. 1984. Retinal resolving power and sensitivity of the photopic system in seven haplochromine species (Teleostei, Cichlidae). Neth. J. Zool. 34: 197-209. 
MEYer, A. 1986. Changes in behavior with increasing experience with a novel prey in fry of the Central American cichlid, Cichlasoma managuense (Teleostei: Cichlidae). Behaviour 98: 145-167.

Mittelbach, G.G. 1981. Foraging efficiency and body size: a study of optimal diet and habitat use by bluegills. Ecology 62: 1370-1386.

MrtTElBACH, G.G. 1984. Predation and resource partitioning in two sunfisshes (Centrarchidae). Ecology 65: 499-513.

Mittelbach, G.G. 1986. Predator-mediated habitat use: some consequences for species interactions. Environ. Biol. Fishes 16: 159-169.

MULler, H. 1952. Bau und Wachstum der Netzhaut des Guppy (Lebistes reticulatus). Zool. Jahrb. 63: 275-324.

MUNTz, W.R.A. 1974. Comparative aspects in behavioral studies of vertebrate vision, p. 155-226. In H. Davson and L.T. Graham, Jr. [ed.] The eye Vol. 6. Academic Press, New York, N.Y.

Muntz, W.R.A. 1990. Stimulus, environment and vision in fishes, p. 491-511. In R.H. Douglas and M.A.B. Djamgoz [ed.] The visual system of fish. Chapman and Hall, London.

Neave, D.A. 1984. The development of visual acuity in larval plaice (Pleu ronectes platessa L.) and turbot (Scophthalmus maximus L.). J. Exp. Mar. Biol. Ecol. 78: 167-175.

NORTHMORE, D.P.M., AND C.A. DvoraK. 1979. Contrast sensitivity and acuity of the goldfish. Vision Res. 19: 255-261

O'Brien, W.J., H.I. Browman, AND B.I. EvaNS. 1990. Search strategies of foraging animals. Am. Sci. 78: 152-160.

O'BriEN, W.J., AND B.I. Evans. 1991. Saltatory search behavior in five species of planktivorous fish. Verh. Int. Ver. Limnol. 24: 2371-2376.

O'Brien, W.J., B.I. Evans, AND H.I. Browman. 1989. Flexible search tactics and efficient foraging in saltatory searching animals. Oecologia 80 : $100-110$.

O'Brien, W.J., N.A. Slade, and G.L. Vinyard. 1976. Apparent size as the determinant of prey selection by bluegill sunfish (Lepomis macrochirus). Ecology 57: 1304-1310.

OsenberG, C.W., E.E. Werner, G.G. MittelbaCh, and D.J. Hall. 1988 Growth patterns in bluegill (Lepomis macrochirus) and pumpkinseed ( $L$. gibbosus) sunfish: environmental variation and the importance of ontogenetic niche shifts. Can. J. Fish. Aquat. Sci. 45: 17-26.

OTTEN, E. 1981. Vision during growth of a generalized Haplochromis species: H. elegans Trewavas 1933 (Pisces, Cichlidae). Neth. J. Zool. 31: $650-700$.

POWERS, M.K., AND P.A. RAYMOND. 1990. Development of the visual system, p. 419-442. In R.H. Douglas and M.A.B. Djamgoz [ed.] The visual system of fish. Chapman and Hall, London.

RAHMANN, H., G. JESERICH, AND I. ZEUTZIUS. 1979. Ontogeny of visua acuity of rainbow trout under normal conditions and light deprivation. Behaviour 68: 315-322.

SCHWASSMANN, H.O., AND L. KRUGER. 1965. Organization of the visual projection upon the optic tectum of some freshwater fish. J. Comp. Neurol. 124: 113-126.
SIVAK, I.G. 1973. Interrelation of feeding behavior and accommodation lens movements in some species of North American freshwater fishes. J. Fish. Res. Board Can. 30: 1141-1146.

Sivak, J.G, 1990. Optical variability of the fish lens, p. 63-80. In R.H. Douglas and M.A.B. Djamgoz [ed.] The visual system of fish. Chapman and Hall, London.

SIVAK, J.G., AND W.R. BoBIER. 1978. Chromatic aberration of the fish eye and its effect on refractive state. Vision Res. 18: 453-456

TAMURA, T., AND W.J. WisBy. 1963. The visual sense of pelagic fishes especially the visual axis and accommodation. Bull. Mar. Sci. Gulf Caribb. 13: 433-448.

VINYARD, G.L., AND W.J. O'BRIEN. 1976. Effects of light and turbidity on the reactive distance of bluegill sunfish (Lepomis macrochirus). J. Fish. Res. Board Can. 33: 2845-2849.

WAGNER, H.-J. 1978. Cell types and connectivity patterns in mosaic retinas. Adv. Anat. Embryol. Cell Biol. 55(3): 81 p.

WAHL, C.M., E.L. Mills, W.N. McFarland, and J.S. DeGisi. 1993. Ontogenetic changes in prey selection and visual acuity of the yellow perch, Perca flavescens. Can. J. Fish. Aquat. Sci. 50: 743-749.

WALtON, W.E., N.G. HAIRSTON, JR., AND J.K. WETtERER. 1992. Growthrelated constraints on diet selection by sunfish. Ecology $73: 429-438$.

WANZENBÖCK, J. 1992. Ontogeny of prey attack behaviour in larvae and juveniles of three European cyprinids. Environ. Biol. Fishes 33: 23-32.

WANZENBÖCK, J., AND F. SCHIEMER. 1989. Prey detection in cyprinids during early development. Can. J. Fish. Aquat. Sci. 46: 995-1001.

WERNER, E.E., AND D.J. HALl. 1974. Optimal foraging and the size selection of prey by the bluegill sunfish (Lepomis macrochirus). Ecology 55: 1042-1052.

WERnER, E.E., AND D.J. HALl. 1988. Ontogenetic habitat shifts in the bluegill: the foraging rate - predation risk tradeoff. Ecology 69: $1352-1366$.

Werner, E.E., G.G. Mittelibach, D.J. Hall, and J.F. Gilliam. 1983 Experimental tests of optimal habitat use in fish: the role of relative profitability. Ecology 64: 1525-1539.

WERNER, R.G. 1967. Intralacustrine movements of bluegill fry in Crane Lake, Indiana. Trans. Am. Fish. Soc. 96: 416-420.

WETtERER, J.K. 1989. Mechanisms of prey choice by planktivorous fish: perceptual constraints and rules of thumb. Anim. Behav. 37: 955-967.

Wetterer, J.K., AND C.J. Bishop. 1985. Planktivorous prey selection reactive field volume model versus the apparent size model. Ecology 66: $457-464$.

WILLIAMSON, M., AND A. KEAST. 1988. Retinal structure relative to feeding in the rock bass (Ambloplites rupestris) and bluegill (Lepomis macrochirus). Can. J. Zool. 66: 2840-2846.

ZAunREITER, M., H. JuNGER, AND K. KoTRSCHAL. 1991. Retinal morphology of cyprinid fishes: a quantitative histological study of ontogenetic changes and interspecific variation. Vision Res. 31: 383-394. 